\title{
Metasztatikus ovariumcarcinoma kemoterápiás kezelése nyolc éven át
}

\author{
Horváth Dorottya Katalin dr. - Kósa Judit dr. \\ Futó Ildikó dr. - Telekes András dr. \\ Bajcsy-Zsilinszky Kórház és Rendelőintézet, Onkológiai Osztály, Budapest
}

\begin{abstract}
A 48 éves nőbetegnél 2006-ban pleuralis folyadék, hasi fájdalom és ascites miatt indult kivizsgálás során a panaszok és tünetek hátterében elörehaladott stádiumú ovariumcarcinoma igazolódott, amely miatt hysterectomia és kétoldali adnexectomia történt. A szövettani vizsgálat FIGO IIIB stádiumú papillaris adenocarcinomát mutatott. Posztoperatívan a standard, 6 ciklus taxol-carboplatin kezelésben részesült. 2008-ban retroperitonealis nyirokcsomó-metasztázisok miatt reindukciós taxol-carboplatin kezelés indult, azonban progresszió miatt hamar kezelésváltás vált szükségessé. Ezt követően még hatféle kemo- vagy biológiai terápiás kezelésben részesült, köztük a hetedik vonalban off-label megigényelt FOLFOX-4-kezelés. A FOLFOX-4-terápia mellett is jelentős regresszió igazolódott, a progressziómentes túlélés mintegy 9 hónap volt. A váltott kezelések során a beteg mindvégig kielégítő általános állapotban volt, lényegében tolerálható mellékhatások mellett. A teljes túlélés 98 hónapnak bizonyult. Az eset jól mutatja a személyre szabott, váltott kemoterápiás kezelés sikerességét már a diagnózis idején is előrehaladott állapotú petefészek-daganatnál is. Orv. Hetil., 2016, 157(44), 1769-1773.
\end{abstract}

Kulcsszavak: petefészek-daganat, váltott kemoterápia, FOLFOX-4-terápia

\section{Chemotherapeutic treatment of metastatic ovarian cancer for 8 years. Case report}

\begin{abstract}
The authors present the history of a 48-year-old woman, who developed pleural effusion, abdominal pain and ascites due to an advanced ovarian cancer. She underwent hysterectomy and bilateral adnexectomy in 2006, and histology revealed FIGO IIIB papillary adenocarcinoma. After surgery the patient recieved the standard, 6 cycle taxol-carboplatin therapy. Taxol-carboplatin therapy was reinitiated because of retroperitoneal lymph node metastases in 2008, but soon the therapy had to be changed because of progression. Thereafter the patient recieved 6 different types of chemo- and biological therapy including the off-label FOLFOX-4 treatment at seventh line. Significant regression in response to FOLFOX-4 therapy was confirmed with a progression free survival of about 9 months. The general condition of the patient was satisfying during the whole chemotherapy, and the side effects were tolerable. The overall survival was 98 months. This case history is a good example for the success of individualized, long term chemotherapy even if ovarian tumor diagnosed at advanced stage as it happened in this case.
\end{abstract}

Keywords: ovarian cancer, changed chemotherapy, FOLFOX-4 therapy

Horváth, D. K., Kósa, J., Futó, I., Telekes, A. [Chemotherapeutic treatment of metastatic ovarian cancer for 8 years. Case report]. Orv. Hetil., 2016, 157(44), 1769-1773.

(Beérkezett: 2016. július 14.; elfogadva: 2016. augusztus 17.)

\section{Rövidítések}

$\mathrm{CEP}=$ ciklofoszfamid + epirubicin + ciszplatin $;$ FOLFOX $=$ kalcium-folinát + 5-fluorouracil + oxaliplatinium; GGT = gamma-glutamiltranszferáz; GOT = glutamát-oxálacetát-transz- amináz; GPT = glutamát-piruvát-transzamináz; OGYÉI = Országos Gyógyszerészeti és Élelmezés-egészségügyi Intézet; $\mathrm{PFS}=$ progressziómentes túlélés; $\mathrm{VIP} / \mathrm{E}=$ vepesid + ifoszfamid + ciszplatin 
Az ovariumcarcinoma a második leggyakrabban előforduló nőgyógyászati daganat az endometriumcarcinoma után és az 5. leggyakoribb daganatos halálok a nők körében [1]. Mivel a tünetek nagyrészt nem specifikusak a betegségre, gyakran csak késői stádiumban diagnosztizálják [2]. A metasztatikus petefészek-carcinomás betegek hosszú távú túlélése ritka. Az előrehaladott stádiumban diagnosztizált betegek 75-80\%-ánál észlelhetó relapsus az első 5 évben [3], illetve az előrehaladott stádiumú petefészektumorban szenvedő nők mindössze 20\%-a él 12 évvel az első kezelés befejezését követően, a kombinált kezelés (mütét, kemoterápia) ellenére is [4]. A metasztatikus betegséggel diagnosztizált nók 5 éves túlélése 28,8\% a National Cancer Institute SEER adatbázisa szerint [5]. A különböző stádiumú betegek 5 éves túlélését az l. ábrán tüntettük fel.

Esetismertetésünk során egy olyan beteg kórtörténetét mutatjuk be, aki a diagnózistól számítva 8 évig élt $(98$ hónap), és ezen idő alatt hétféle protokoll szerinti kemoterápiás kezelésben részesült.

\section{Esetismertetés}

Betegünk távolabbi anamnézisében appendectomián és gyógyszeresen kezelt hypertonián kívül lényeges megbetegedés nem szerepelt. Daganatos betegségére 2006 nyarán derült fény, akkor 48 éves volt. Egy másik budapesti intézményben jelentkezett hasi fájdalommal és két hét alatt kialakult jelentős haskörfogat-növekedéssel. A pleuralis folyadék, ascites és hasi fájdalom hátterében előrehaladott stádiumban lévő ovariumcarcinoma igazolódott. Hysterectomiát, kétoldali salpingoo-ophorectomiát végeztek, radikális omentumreszekcióval kiegészítve.

A mútéti szövettan: Adenocarcinoma papillare ovarii, cystadenocarcinoma metasztázisa a csepleszben, TNMstádium: pT3b Nx Ml, FIGO IIIB. Mellékleletként leiomyoma corporis uteri.

A mútét után a standard taxol-carboplatin kemoterápiából kapott 6 ciklust, ezt követően pedig hormonterápiában (medroxiprogeszteron) részesült. A 2008. április-

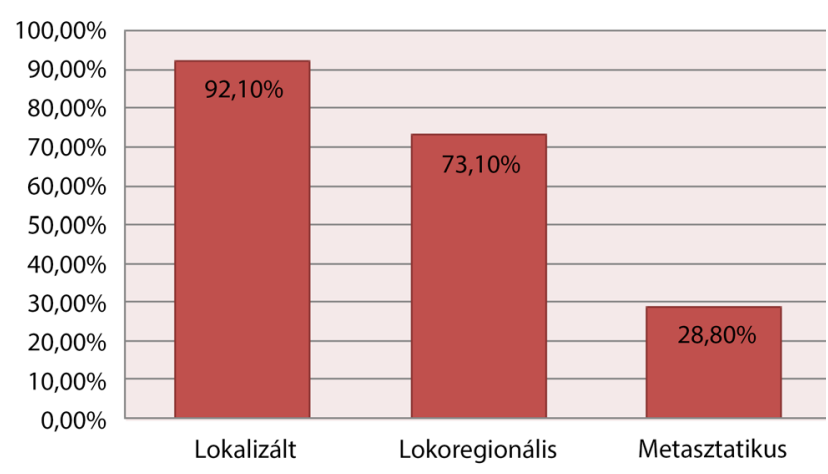

1. ábra $\quad$ Petefészektumoros betegek 5 éves túlélése a National Cancer Institute SEER adatbázisa szerint a 2004 és 2010 közötti adatokra vonatkoztatva $[5]$ ban végzett kontrollvizsgálatok közül a hasi CT-n a retroperitoneumban a vena cava inferior és az aorta között, valamint a vena cava inferior mögött több megnagyobbodott patológiás méretú, $25 \times 30$ mm-es nyirokcsomó ábrázolódott. A tumormarkerek közül a CA-125 értéke emelkedett $(149,8)$ volt. 1991-ben Markman és mtsai igazolták, hogy minél több idő telik el a primer platinaalapú kezeléstől a relapsusig, annál nagyobb esélylyel hat kedvezően a másodvonalban adott platinabázisú kemoterápia [6]. Reindukciós taxol-carboplatin kezelést indítottak, hiszen a relapsusig eltelt idő 6 hónapnál többnek bizonyult, így platinaszenzitívnek véleményezték [7]. A 2. ciklus után készült kontroll-CT-vizsgálatok azonban további progressziót igazoltak, ezért kezelésváltás volt szükséges. A 8 széria CEP-kezelés alatt malignus betegsége regrediált. A 2009 szeptemberében igazolódott ismételt progresszióra való tekintettel gemzar-carboplatin kezelést kezdtek, amelyből 5 ciklust kapott. Ekkor - 2010 februárjában - ismételten progresszió következett be a hasi-kismedencei CT és transvaginalis ultrahang alapján. Negyedik vonalban liposzomális doxorubicinkezeléssel próbálkoztak, azonban az első infúzió közben kialakult súlyos oedemával járó anaphylaxiás reakció miatt a kezelést leállították. Az anaphylaxia dózisfüggetlen gyógyszerreakció [8]. A liposzomális doxorubicinnal kapcsolatban 2014-ben egy 69 éves, synovialis sarcomában szenvedő nő hasonló reakcióját publikálták liposzomális doxorubicinkezelés mellett [9], egyéb forrás a szakirodalomban nem áll rendelkezésre. Terápiaváltás történt, 6 ciklus Hycamtin- (topotecan-) kezelést kapott. A további terápia megkönnyítése céljából 2010 szeptemberében port-A-cath típusú állandó vénakanül beültetését végezték el, amely kapcsán egy hónappal később szepszis, majd jobbszívfél-endocarditis és a tricuspidalis billentyü medialis vitorláján felrakódott vegetációból pulmonalis szórás alakult ki. Kombinált antibiotikus kezelésben részesült, azonban állapota csak lassan stabilizálódott. További kemoterápiás kezelést nem terveztek.

A beteg 2012 januárjában jelentkezett osztályunkon. Utolsó kontrollvizsgálata 2011 júliusában volt, ekkor hasi-kismedencei CT készült, amelyen a paraaorticus nyirokcsomó-metasztázisok kifejezett progresszióját írták le. A 2012 elején végzett restaging kontroll-CT-k alapján intrapulmonalis metasztázisai nem voltak, hasi státuszában további progresszió ábrázolódott: az aorta descendens mentén, az ér és a gerinc között mindkét oldalon patológiás nyirokcsomók, retroperitonealis lymphadenopathia, kifejezetten inhomogén májszerkezet. A CA-125 értéke $222 \mathrm{U} / \mathrm{ml}$ volt.

Kemoterápiás kezelésként 5. vonalban VIP/E kezelést indítottunk, amelyből 6 ciklusban részesült. A terápia hatására a CA-125 értéke normalizálódott, a kontrollCT-k a folyamat regresszióját (parciális remisszió) igazolták. 6 széria után exploratív laparotomiát és lymphadenectomiát terveztünk, azonban a tervezett mútét anaesthesiologiai kontraindikáció miatt nem történt 
meg. A beteg kérésére szoros obszervációt végeztünk 2012 szeptemberétől. Tumormarkerszintje lassan emelkedésnek indult, majd 2013 tavaszán a CT-vizsgálatokon progresszió igazolódott az intraabdominalis nyirokcsomó-metasztázisok vonatkozásában.

Az ismételt progresszió megjelenésekor bevacizumabkezelést terveztünk, amely azonban off-label kezelésnek számított, tekintettel arra, hogy a bevacizumab petefészektumorban csak első vonalban volt választható. 2005 ben publikáltak egy esetet, ahol a 3 hetenként adott 15 $\mathrm{mg} / \mathrm{kg}$ bevacizumab 11 különböző kemoterápiát, illetve sugárterápiát követően hatásosnak bizonyult és mintegy 5 hónapos PFS-t biztosított a betegnek [10]. A klinikai vizsgálatok ezt a hatást megerősítették (GOG protocol 218 [11], ICON7 [12], AURELIA Trial [13], OCEANS Trial [14]). Ezért off-label kérelmet nyújtottunk be az OGYÉI felé bevacizumabkezelésre, amelyet meg is kaptunk. Az első kontroll alkalmával azonban részleges regresszió mellett progresszió is ábrázolódott. A nyirokcsomóáttétek nagy részének mérete csökkent, azonban a májmetasztázisok méretben és számban is progrediáltak. A progressziót a CA-125-érték is megerősítette, amely $1360 \mathrm{U} / \mathrm{ml}$ volt. Érdemes megemlíteni, hogy a tumormarkerek közül a CA 15-3 szint változásán is nyomon követhető a tumorstátusz alakulása. 1988-ban Scambia és mtsai foglalkoztak a CA 15-3 szerepével és azt találták, hogy a malignus petefészektumoros betegek 71\%-ában emelkedett volt ezen tumormarker szérumszintje, és az emelkedés mértéke egyenes arányban állt a tumorstádiummal. Benignus ovarialis elváltozások esetében mindössze 20\%-ban volt emelkedett a CA 15-3 szint [15].

Egy klinikai vizsgálatban igazolták a FOLFOX-4 kemoterápia hatékonyságát erősen előkezelt, előrehaladott epithelialis petefészek-carcinomában szenvedő betegek esetén [16]. A vizsgálatban a 28 kezelt betegből 25\%-nál észleltek részleges remissziót, 21,4\%-uknál pedig stabil betegséget. Hetedik vonalban ezért off-label FOLFOX kemoterápiás kezelést kezdtünk, amely mellett a CA-125 értéke jelentősen csökkent (210), a képalkotó vizsgálatokon is egyértelmü regresszió ábrázolódott, hiszen mind a hepaticus, mind a retroperitonealis és peritonealis metasztázisok mérete és száma csökkent. A kezelések során kialakuló, a beteg számára tolerálhatatlan, polyneuropathiás panaszok következtében azonban a beteg kérésére a FOLFOX kemoterápiás kezelést a 11 . ciklus után abbahagytuk. Az 1. táblázat mutatja az osztályunkon kapott kezelések fajtáját, ciklusszámát és az elért progressziómentes túlélést.

Az utolsó FOLFOX-kezelés után további aktív onkológiai kezelésre nem kerülhetett sor a betegség gyors progressziója és az ennek következtében jelentkező állapotromlás miatt. Ureterkompresszió következményeként veseelégtelenség alakult ki 2014 szeptemberére. Terhelésre jelentkező dyspnoe lépett fel, amelynek hátterében nagy mennyiségű mellkasi folyadékot igazoltunk, amit több alkalommal lebocsátottunk. A citológia malignus sejtek jelenlétét igazolta a pleuralis folyadékban.
1. táblázat | Különböző kezelések ciklusszáma és az általuk elért progressziómentes túlélés

\begin{tabular}{lcc}
\hline $\begin{array}{l}\text { Terápia (kemo- vagy } \\
\text { biológiai kezelés) }\end{array}$ & Ciklusszám & Progressziómentes túlélés \\
\hline VIP/E & 6 & 14 hónap \\
Bevacizumab & 4 & 4 hónap \\
FOLFOX-4 & 11 & 9 hónap \\
\hline
\end{tabular}

FOLFOX-4 = kalcium-folinát +5 -fluorouracil + oxaliplatinium; VIP $/ \mathrm{E}=\mathrm{ve}$ pesid + ifoszfamid + ciszplatin

Betegünk összesen 8 évet élt (98 hónap) a csepleszmetasztázist adó petefészek-carcinoma diagnózisa óta, és általános állapota még az utolsó kemoterápiás kezelések alkalmával is egészen élete utolsó 2-3 hónapjáig kielégítő volt. A kezelések során mért tumormarkerszinteket a 2. ábrán tüntettük fel. Az ábrán látható, hogy a két tumormarker lefutása a vizsgált időszak alatt szinte identikus volt.

\section{Mellékhatások}

A kemoterápiás kezelések önmagukban is okozhatnak jelentős mellékhatásokat, azonban egy többszörösen előkezelt betegnél a mellékhatások akár össze is adódhatnak, így az idő előrehaladásával a mellékhatások egyre súlyosabb fokúak lehetnek, és egyre gyakrabban jelentkezhetnek az akut reakcióktól kezdve az elhúzódóan kialakult mellékhatásokig. A dokumentációk szerint a liposzomális doxorubicin- (Caelyx-) kezelés által kiváltott oedemával járó anaphylaxiás reakción kívül a többi kemoterápiás kezelés mellett ilyen mértékú akut reakció

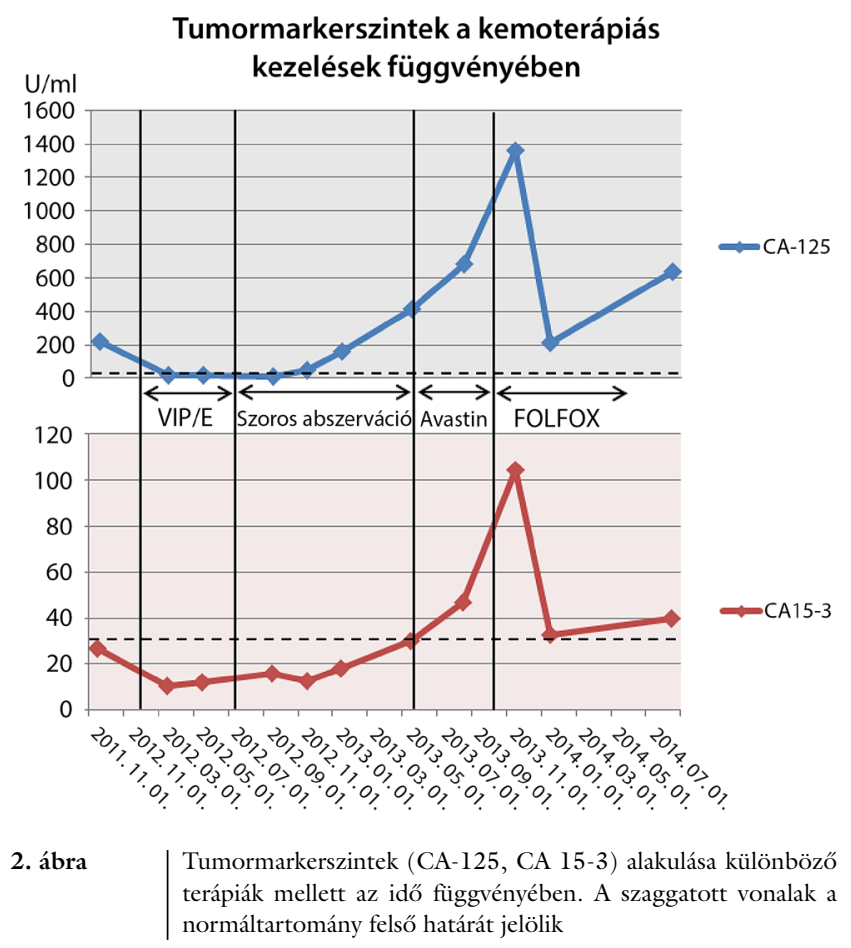




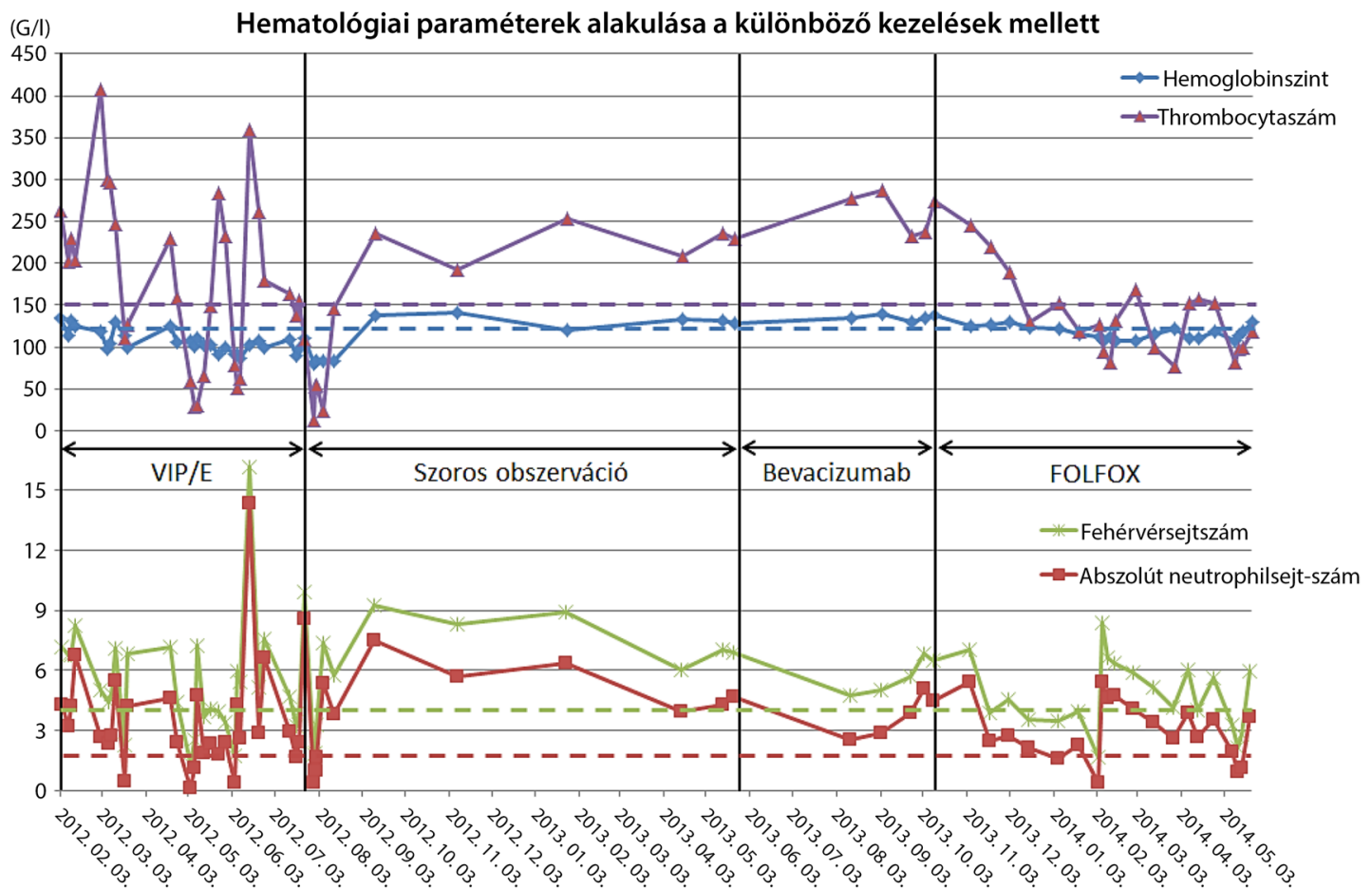

3. ábra $\mid \begin{aligned} & \text { Hematológiai paraméterek alakulása a különböző kezelések mellett. A szaggatott vonalak a különböző hematológiai paraméterek normálszintjének } \\ & \text { alsó határát jelölik }\end{aligned}$

nem alakult ki. Betegünk esetében retrospektíven analizáltuk az utolsó három (osztályunkon végzett) kemoterápiás rezsim közben mért hematológiai (hemoglobin-, thrombocyta-, fehérvérsejt- és szegmentszámot) és vesefunkciós paramétereket (karbamid, kreatinin), valamint a májfunkciós enzimek (szérumbilirubin, direkt bilirubin, ASAT, ALAT, GGT) alakulását, illetve a fellépett egyéb mellékhatásokat.

Hematológiai szempontból mindhárom sejtvonal érintettsége legfóképp a VIP/E kezelés mellett jelentkezett, míg a FOLFOX-4 kemoterápia mellett kevésbé súlyosan, de a thrombocytaszám és fehérvérsejtszám csökkenését figyeltük meg a kezeléseket követóen (3. ábra). A vérképző rendszert érintő mellékhatások közül kiemelendő az utolsó VIP/E kemoterápia után kialakult purpurákkal járó, thrombocytaszuszpenziót igénylő gravis thrombocytopenia, valamint a granulocytastimuláló faktort igénylő gravis neutropenia.

A máj- és vesefunkciós markerek lényegében fiziológiás tartományban voltak az összes kezelés mellett, annak ellenére, hogy itt már sokadik vonalban adott kezelésekrôl beszélünk (4. és 5 . ábra).

Gastrointestinalis tünetek leginkább a VIP/E kezelés mellett jelentkeztek, közöttük előfordult émelygés, hányinger, hasi fájdalmak és hasmenés. Általános mellékhatásként ezenkívül megemlítendő a kezelések során előfordult gyengeség, fáradékonyság. Egy alkalommal kollaptiform rosszullét jelentkezett, ennek összefüggése a terápiával nem volt egyértelmú.

A bevacizumabterápia mellett súlyos mellékhatás nem alakult ki. A FOLFOX-4-terápia során számolnunk kellett az oxaliplatin ismert mellékhatásaival, amelyek közül

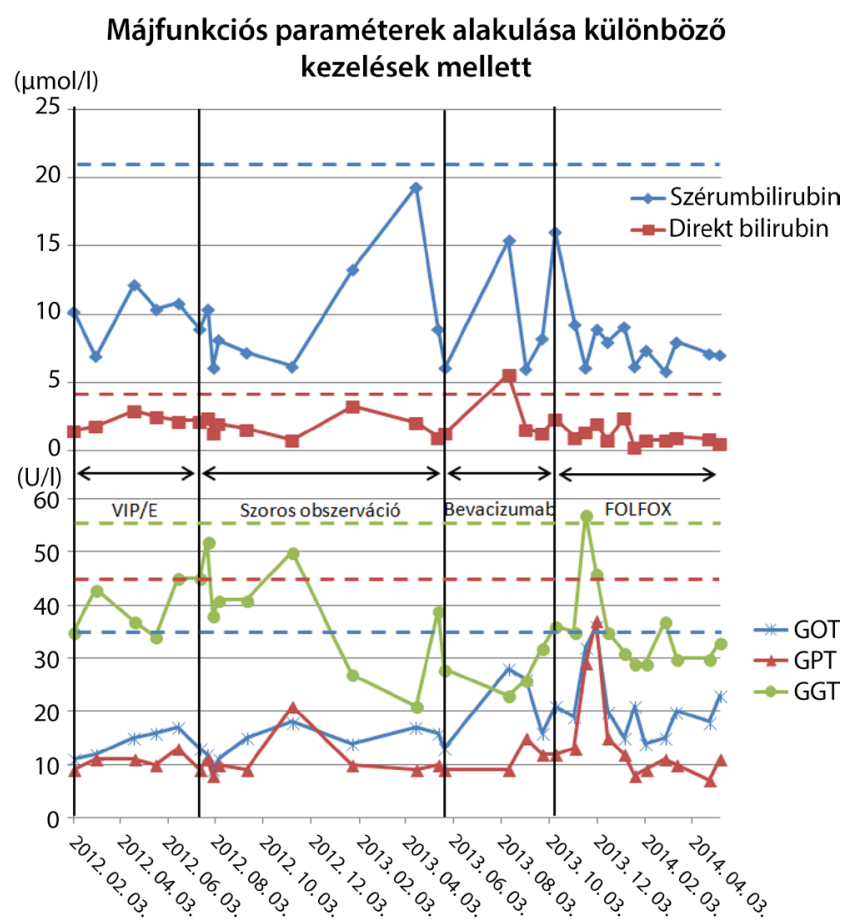

4. ábra

Májfunkciós paraméterek alakulása különböző terápiák mellett az idő függvényében. A szaggatott vonalak a különböző májfunkciós paraméterek normáltartományának felső határát jelölik

GGT = gamma-glutamiltranszferáz; GOT = glutamát-oxálacetát-transzamináz; GPT = glutamát-piruvát-transzamináz

a beteg számára leginkább zavaró tünet a neuropathia volt, amely miatt, a beteg kérésére, végül a kezelést 11 ciklus után leállítottuk. 


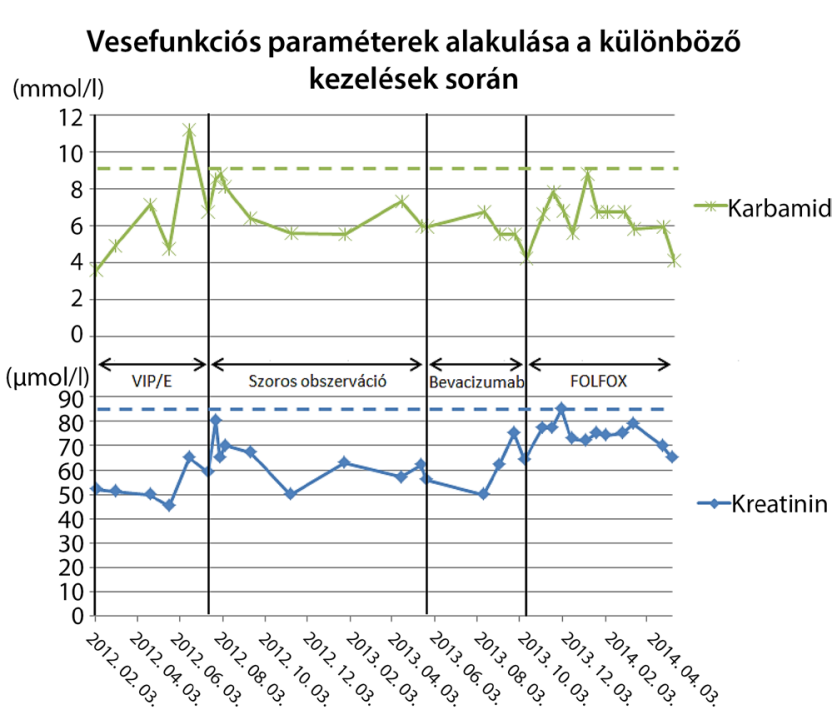

5. ábra \begin{tabular}{|l} 
Vesefunkciós paraméterek alakulása a különböző kezelések so- \\
rán az idő függvényében. A szaggatott vonalak a karbamid- és \\
kreatininszint normál felső határát jelölik
\end{tabular}

Megbeszélés

Metasztatikus petefészektumor esetén a másod-, harmadvonalbeli kezelést követő progresszió esetén is érdemes kemoterápiás kezelést adni, hiszen mérhető és látványos regresszió érhető el akár hetedik vonalbeli kezelés hatására is. A finanszírozott protokollokon kívül létezik hatásos kemoterápia, amelyek off-label kezelésként elérhetők. A gastrointestinalis tumorokban elfogadott és első vonalban alkalmazott FOLFOX-4 kemoterápiás kezelés hatékonysága ovariumtumoros betegünknél hetedik választású kezelésként közel 9 hónapos PFS-t biztosított. Annak ellenére, hogy páciensünk az évek során többválasztású kemoterápiás kezelésben is részesült, általános állapota szinte mindvégig kielégítő volt, és a mellékhatás-menedzsmentnek köszönhetően a kezeléseket jól tolerálta. Betegünk teljes túlélése a diagnózistól számítva összesen 98 hónapra tehető. (Már a diagnózis idején is IV. stádiumú beteg volt!) Váltott kemoterápiás kezelésekkel a beteg élete jelentősen meghosszabbítható, ezért az eltérő hatású szereket tartalmazó protokollok szekvenciális adása mindig mérlegelendő, amennyiben ezt a beteg állapota lehetővé teszi.

Az onkológiában az egyéni mérlegelés alapvetően fontos, hiszen a daganatos betegek kezelése egyre inkább az individualizált terápiák felé halad.

Anyagi támogatás: A szerzők anyagi támogatásban nem részesültek.

Szerzői munkamegosztás: H. D. K.: Irodalmi áttekintés, a dolgozat szövegének szerkesztése. K. J.: A beteg kezelése. F. I.: Az elkészült kézirat áttekintése, javaslatok adása. T. A.: Terápiás döntések meghozatala, az elkészült kézirat áttekintése, javaslatok adása.
A cikk végleges változatát valamennyi szerző elolvasta és jóváhagyta.

Érdekeltségek: A szerzőknek nincsenek érdekeltségeik.

\section{Irodalom}

[1] Montes, A. F., Gómez, J. G., Viejo, M. N., et al.: Epidemiology and etiology of ovarian cancer. In: Farghaly, S. A. (ed.): Ovarian Cancer-Basic Science Perspective. INTECH, Rijeka, 2012.

[2] Gaitskell, K., Martinek, I., Bryant, A., et al.: Angiogenesis inhibitors for the treatment of ovarian cancer. Cochrane Database Syst. Rev., 2011, (9), CD007930.

[3] Heinz, A. P., Odicino, F., Maisonneuve, P., et al.: Carcinoma of the ovary. FIGO sixth annual report on the results of treatment in gynecological cancer. Int. J. Gynaecol. Obstet., 2006, 95(Suppl. 1), S161-S192.

[4] Narod, S.: Can advanced-stage ovarian cancer be cured? Nat. Rev. Clin. Oncol., 2016, 13(4), 255-261.

[5] SEER Stat Fact Sheets: Ovarian Cancer. http://seer.cancer.gov/ statfacts/html/ovary.html

[6] Markman, M., Rothman, R., Hakes, T., et al.: Second-line platinum therapy in patients with ovarian cancer previously treated with cisplatin. J. Clin. Oncol., 1991, 9(3), 389-393.

[7] Harries, M., Gore, M.: Part II: Chemotherapy for epithelial ovarian cancer-treatment of recurrent disease. Lancet Oncol., 2002, $3(9), 537-545$.

[8] Edwards, I. R., Aronson, J. K.: Adverse drug reactions: definitions, diagnosis, and management. Lancet, 2000, 356 (9237), 1255-1259.

[9] Sharma, L. R., Subedi, A., Shah, B. K.: Anaphylaxis to pegylated liposomal doxorubicin: A case report. West Indian Med. J., 2014, 63(4), 376-377.

[10] Monk, B. J., Choi, D. C., Pugmire, G., et al.: Activity of bevacizumab (rhuMAB VEGF) in advanced refractory epithelial ovarian cancer. Gynecol. Oncol., 2005, 96(3), 902-905.

[11] Burger, R. A., Brady, M. F., Bookman, M. A., et al., for the Gynecologic Oncology Group: Incorporation of bevacizumab in the primary treatment of ovarian cancer. N. Engl. J. Med., 2011, 365(26), 2473-2483.

[12] Perren, T. J., Swart, A. M., Pfisterer, J., et al., for the ICON7 Investigators: A phase 3 trial of bevacizumab in ovarian cancer. N. Engl. J. Med., 2011, 365(26), 2484-2496.

[13] Pujade-Lauraine, E., Hilpert, F., Weber, B., et al.: Bevacizumab combined with chemotherapy for platinum-resistant recurrent ovarian cancer: The AURELIA open-label randomized phase III trial. J. Clin. Oncol., 2014, 32(13), 1302-1308.

[14] Aghajanian, C., Blank, S. V., Goff, B. A., et al.: OCEANS: a randomized, double-blind, placebo-controlled phase III trial of chemotherapy with or without bevacizumab in patients with platinum-sensitive recurrent epithelial ovarian, primary peritoneal, or fallopian tube cancer. J. Clin. Oncol., 2012, 30(17), 2039-2045.

[15] Scambia, G., Benedetti Panici, P., Baiocchi, G., et al.: CA 15-3 serum levels in ovarian cancer. Oncology, 1988, 45(3), 263-267.

[16] Lee, H. J., Kim, H. S., Park, N. H., et al.: Feasibility of oxaliplatin, leucovorin, and 5-fluorouracil (FOLFOX-4) chemotherapy in heavily pretreated patients with recurrent epithelial ovarian cancer. Cancer Res. Treat., 2013, 45(1), 40-47.

(Horváth Dorottya Katalin, Budapest, Maglódi út 89-91., 1106 e-mail: horvath.dorottya@bajcsy.hu) 